\title{
PENGARUH TERAPI MUSIK TRADISIONAL TERHADAP TINGKAT DEPRESI PADA PASIEN GAGAL GINJAL KRONIK YANG MENJALANI HEMODIALISA DI RUANG HEMODIALISA DR. SOEHADI PRIJONEGORO SRAGEN
}

\author{
Lina Puji Astuti ${ }^{1}$ \\ ${ }^{1}$ Kementerian Kesehatan Politeknik Kesehatan Surakarta Jurusan Keperawatan \\ e-mail : zea funtima@yahoo.com \\ Diterima : 2 Mei 2018, Disetujui : 9 Mei 2018
}

\begin{abstract}
Backgound. Largely, patients with chronic renal failure undergoing hemodialysis are depressed. One therapy to reduce the rate of depression is music therapy, music therapy can respond the body into relaxation and calm that can reduce levels of depression. The aim of this study is (1) Determine the level of depression in patients with chronic renal failure (2) Determine the effect of music therapy on the level of depression in patients with chronic renal failure. The research methods. This research used a pre-post test design with a one-group pre-post test data analysis used by the Wilcoxon test. Researches. There was a significant effect of music therapy on decreased levels of depression in patients with chronic renal failure undergoing hemodialysis at Dr. Soehadi Prijonegoro Hospital, Sragen. This is evidenced by the Wilcoxon test which was obtained $p=0.000$. Because the value of $p<0.05$, so that there is the effect of music therapy on depression levels. Conclusion. There was a significant effect of music therapy on decreased levels of depression in patients with chronic renal failure undergoing hemodialysis at Dr. Soehadi Prijonegoro Hospital, Sragen
\end{abstract}

Keywords: Chronic Renal Failure Hemodialisa, Music Therapy, Depression

\section{PENDAHULUAN}

Gagal ginjal kronik adalah gangguan fungsi ginjal yang progresif, irreversibel, kemampuan tubuh gagal untuk mempertahankan metabolisme dan keseimbangan cairan dan elektrolit, menyebabakan uremia (retensi urea dan sampah nitrogen lain dalam darah) (Smeltzer \& Bare, 2001). Berdasarkan perkiraan WHO pada tahun 2012, angka harapan hidup penduduk Indonesia mencapai 71 tahun, dan pada tahun yang sama WHO memperkirakan angka kematian yang disebabkan oleh penyakit kronis di Indonesia mencapai 54\% dari seluruh penyebab kematian, melebihi angka kematian yang disebabkan karena penyakit menular dan kecelakaan. Salah satu penyakit kronis yang angka kejadiannya diperkirakan meningkat setiap tahunnya adalah penyakit gagal ginjal kronis (Sundara Y.T, 2014).

Ginjal pada penderita gagal ginjal kronik sudah mengalami kerusakan sehingga diperlukan terapi seperti cuci darah (Hemodialisis) dan transplatansi organ ginjal (Suwitra, 2009). Terapi transplatansi ginjal jarang dilakukan oleh penderita gagal ginjal karena biaya yang terlalu mahal, sehingga banyak pasien gagal ginjal kronik yang melakukan terapi hemodialisis dibandingkan transplatansi ginjal (National Kidney and Urologic 
Disease information Clearinghousel NKUDIC (2006).

Pasien gagal ginjal kronik yang menjalani program terapi seperti hemodialisa dapat menyebabkan gangguan fisologis dan psikologis. Gangguan fisiologis contohnya pasien mengalami penurunan berat badan, nafsu makan berkurang, gangguan tidur dan sebagainya. Gangguan Psikologis misalnya seperti perubahan perilaku, gangguan mental, rasa bersalah, merasa dirinya menjadi beban, perasaan tak berdaya dan masalah tersebut dapat menyebabkan pasien menjadi depresi (Smeltzer \&Bare,2001)

Terapi musik adalah usaha meningkatkan kualitas fisik dan mental dengan rangsangan suara yang terdiri dari melodi, ritme, harmoni, bentuk dan gaya yang diorganisir sedemikian rupa hingga tercipta musik yang bermanfaat untuk kesehatan fisik dan mental, salah satu terapi musik yang dapat diberikan yaitu dengan musik tradisional. Menurut Yamamoto, (2003) terapi musik akan mengurangi pelepasan katekolamin ke dalam pembuluh darah, sehingga konsentrasi katekolamin dalam plasma menjadi rendah. Hal ini mengakibatkan tubuh mengalami relaksasi, denyut jantung berkurang dan menurunkan tingkat stress. Konsentrasi ketekolamin dalam plasma darah mengalami penurunan, sehingga sistem tubuh mengalami relaksasi dan menjadi tenang hal tersebut dapat menurunkan tingkat depresi. Fungsi katekolamin zat dengan struktur kimia tertentu yang berfungsi sebagai hormon atau neurotransmitter.

\section{METODE PENELITIAN}

Penelitian ini termasuk dalam jenis pra-pascates, desain pada penelitian ini menggunakan rancangan penelitian Onegruop pra-post test design yaitu mengungkapkan hubungan sebab akibat dengan cara melibatkan satu kelompok subjek. Suatu kelompok sebelum dikenai perlakuan tertentu diberi pra-tes, kemudian setelah perlakuan, dilakukan pengukuran lagi untuk mengetahui akibat dari perlakuan (Nursalam, 2013).

Responden pada penelitian ini berjumlah 46 responden yang menderita gagal ginjal kronik. Untuk uji hipotesis yang digunakan dalam penelitian ini yaitu uji wilcoxon digunakan untuk mengetahui apakah ada perbandingan tingkat depresi pre dan post pemberian terapi musik.

\section{HASIL PENELITIAN}

Berdasarkan sejumlah 66 responden diketahui bahwa nilai depresi sebelum diberikan terapi musik yaitu dengan depresi normal 26 responden $(42,4 \%)$, depresi sedang 19 responden $(28,8 \%)$, depresi ringan 14 responden $(21,1 \%)$, dan depresi berat 5 responden $(7,6 \%)$. Responden yang telah diberikan terapi musik diketahui bahwa nilai depresi sesudah diberikan terapi musik yaitu depresi normal 38 responden $(57,6 \%)$, depresi ringan 24 responden $(36,4 \%)$, depresi sedang 4 responden $(6,1 \%)$, depresi berat 0 reponden.

Tabel 1. Depresi sebelum diberikan terapi musik

\begin{tabular}{lcc}
\hline $\begin{array}{c}\text { Kategori } \\
\text { depresi }\end{array}$ & Frekuensi & $\begin{array}{c}\text { Presentase } \\
(\%)\end{array}$ \\
\hline Normal & 26 & 42,2 \\
Ringan & 14 & 21,1 \\
Sedang & 19 & 28,8 \\
Berat & 5 & 7,6 \\
Total & 66 & 100,0 \\
\hline
\end{tabular}


Tabel 2. Depresi sesudah diberikan terapi saat diberikan kuesioner mayoritas musik

\begin{tabular}{lllll}
\hline Kategori depresi & Frekuensi & Presentase (Responden yang mempunyai tingkat \\
\hline Normal & 38 & 57,6 & depresi sedang dan ringan dikarenakan \\
Ringan & 24 & 36,4 & responden terlihat tegang dan tidak \\
Sedang & 4 & 6,1 & bersemangat. & \\
Berat & 0 & 0 & Sudden and stuart & \\
Total & 66 & 100,0 & $2006)$
\end{tabular}

Uji normalitas digunakan untuk menyatakan bahwa kebanyakan penyakit mengetahui apakah sebaran atau kronik yang melemahkan tubuh sering distribusi data normal atau tidak. Uji disertai dengan depresi. Hasil penelitian normalitas yang digunakan oleh penulis berbeda dengan teori Canisti (2007) yang adalah uji normalitas Kolmogorov- menyatakan bahwa pasien gagal ginjal Smirnov. Pada penelitian ini tidak kronik yang menjalani hemodialisa dilakukan uji normalitas karena skala mengalami depresi berupa kehilangan data termasuk kategorik.

Diperoleh nilai sig. (2-tailed) adalah 0,000 sehingga terdapat perubahan nilai tingkat depresi sebelum dan sesudah dilakukan terapi musik pada pasien gagal ginjal kronik yang menjalani hemodialisa.

minat melakukan aktivitas yang menyenangkan, rasa bersalah kepada keluarga karena merasa dirinya sebagai beban keluarga, dan perasaan tidak berdaya.

Pada penelitian ini berbeda oleh teori Ayu Fitri Rusanto (2009) yang menyatakan bahwa pasien yang menjalani

Tabel 3. Uji Wilcoxon hemodialisa mayoritas mengalami depresi \begin{tabular}{llll}
\hline & Post terapi-pre terapi berat. Penelitian tersebut diperkuat dengan \\
\hline $\mathrm{Z}$ & $-5,296^{\mathrm{a}}$ & hasil penelitian Canisti (2007) yang
\end{tabular} Asymp.sig.(2-tailed) $\quad .000 \quad$ menyatakan bahwa pasien gagal ginjal

\section{PEMBAHASAN}

Tingkat depresi sebelum diberikan terapi music, Peneliti telah meneliti tingkat depresi pada pasien GGK yang menjalani hemodialisa menggunakan kuesioner Beck Depression Inventory II. Berdasarkan data penelitian pada tabel 1 diketahui bahwa jumlah depresi berat yaitu 5 orang $(7,6 \%)$, depresi ringan 14 orang ( $21,1 \%)$, depresi sedang 19 orang $(28,8 \%)$, depresi normal 28 orang $(42,4 \%)$. Mayoritas responden mempunyai tingkat depresi normal dikarenakan responden sudah dapat beradaptasi terhadap hemodialisa, salah satu responden menyatakan sudah nyaman dilakukan hemodialisa sehingga kronik yang menjalani hemodialisa mengalami depresi berupa kehilangan minat melakukan aktivitas yang menyenangkan, rasa bersalah kepada keluarga karena merasa dirinya sebagai beban, dan perasaan bersalah.

Faktor yang mempengaruhi terjadinya depresi yaitu faktor fisik dan faktor psikologis. Penyebab depresi pada pasien gagal ginjal kronik yaitu faktor fisik yang mencakup adanya penyakit fisik, obat-obatan, atau usia, sedangkan faktor psikologis meliputi pesimis, kekecewaan, harga diri, stress, atau lingkungan keluarga (Lubis, 2009). Penelitian Asri, Marthan, Mariyono, dan Purwanta (2006) menyatakan bahwa dua pertiga dari pasien yang mendapat terapi 
dialisis tidak pernah kembali pada aktivitas atau pekerjaanya seperti sedia kala. Pasien akan kehilangan pekerjaan, penghasilan, kebebasan, harapan umur panjang dan fungsi seksual sehingga dapat menimbulkan kemarahan yang akhirnya yang akhirnya timbul suatu keadaan depresi sekunder sebagai akibat dari penyakit istemik yang mendahuluinya. Oleh karena itu, penderita gagal ginjal kronik yang menjalani hemoialisa dapat mengalami depresi.

a. Tingkat depresi sesudah diberikan terapi musik

Berdasarkan tabel 2 sebagian besar responden yang telah diberikan terapi musik mayoritas pasien mengalami penurunan tingkat depresi dikarenakan mayoritas pasien menyukai dan sudah terbiasa dengan musik tradisional. Hasil analisis peneliti didapatkan depresi normal 38 orang $(57,6 \%)$, depresi ringan 24 orang $(36,4 \%)$, depresi sedang 4 orang $(6,1 \%)$, dan untuk depresi berat pasien sudah tidak mengalaminya setelah diberikan terapi musik dikarenakan pasien sudah merasa tenang dan rileks. Responden yang masih mengalami depresi ringan dan sedang pasien merasa kurang suka dengan musik tradisional responden lebih suka musik jazz, dangdut, dan musik klasik. Ada responden yang baru beberapa kali menjalani hemodialisa yang merasa bahwa dirinya hanya menjadi beban keluarga dan masih ada beberapa responden yang terlihat kurang semangat dan masih ada yang tetap tegang. Menurut (Yamamoto, 2003) terapi musik akan mengurangi pelepasan ketekolamin ke dalam pembuluh darah, sehingga konsentrasi katekolamin dalam plasma menjadi rendah. Hal ini menyebabkan tubuh menjadi rileks, denyut jantung berkurang, dan memberikan ketenangan.

Penelitian ini didukung teori Ayu Fitriya Rusanto (2009) yang menyatakan tingkat depresi sesudah diberikan terapi musik sebagian besar responden mengalami penurunan tingkat depresi.

Penellian didukung oleh teori Tri Yuli Finasari (2008) menyatakan bahwa terapi musik yang disukai mampu menurunka tingkat depresi dan stress karena responden lebih menyukai terapi musik yang disukai.

Pada penelitian tentang pengaruh pemberian terapi musik terhadap depresi, Hasil analisis depresi pada pasien gagal ginjal kronik yang menjalani hemodialisa pre terapi dan post terapi mendapatkan nilai signifikan 0,000 nilai $\mathrm{p}<0,05$ artinya terdapat perubahan nilai depresi sebelum dan sesudah dilakukan terapi musik pada pasien gagal ginjal kronik yang menjalani hemodialisa. Karena dengan mendengarkan musik disukai dapat menghadirkan suasana bahagia, pikiran menjadi tenang, dan mampu memberikan semangat pada jiwa yang kelelahan pada pendengar musik itu sendiri. Menggunakan terapi musik memiliki efek samping lebih kecil serta terapi musik memiliki keuntungan seperti biaya yang dikeluarkan tidak mahal dan lebih praktis, jika dibandingkan dengan obat-obatan. Terapi musik juga dapat membantu secara alami menyehatkan kerja jantung dan menormalkan tekanan darah dengan musik relaksasi. Musik tradisional atau musik tibetan singing bowl, bisa untuk mempengaruhi mood dan untuk memperoleh ketenangan.

Hal ini sesuai dengan penelitian Dwi Agung P, Sri Nyumirah (2007) yang menyatakan bahwa pemberian motivasi spiritual terhadap tingkat depresi 
mengalami penurunan. Musik juga sebagai alat terapi yakni mempengaruhi sistem organ. Musik mampu mengaktifkan memori yang tersimpan di limbik dan mempengaruhi sistem saraf otonom melalui neurotransmitter yang akan mempengaruhi hypothalamus lalu hipofisis. Sehingga merangang hormon sehingga memberikan ketenangan dan rileks.

Hasil penelitian ini berbeda dengn teori Made S, Danang T (2011) hasil penelitian menunjukan bahwa terapi musik tidak berpengaruh untuk menurunkan tekanan darah pada pasien post hemodialisa dikarenakan mayoritas responden merasa terganggu dengan terapi musik yang diberikan.Penelitian ini didukung teori dari Chafin (2004 dalam Clementina 2007) menyatakan bahwa dengan mendengarkan musik klasik dapat mengurangi tingkat depresi dan kecemasan karena musik menstimulus hormon katekolamin didalam tubuh sehingga mengalami relaksasi, yang mengakibatkan penurunan tekanan darah dan denyut jantung.

\section{KESIMPULAN DAN SARAN}

Berdasarkan penelitian yang telah dilakukan terhadap 66 responden tentang Pengaruh terapi musik tradisional terhadap tingkat depresi pada pasien gagal ginjal kronik yang menjalani hemodialisa di Ruang Hemodialisa RSUD Dr. Soehadi Prijonegoro Sragen tahun 2016 didapatkan kesimpulan bahwa tingkat depresi pada pasien yang menjalani hemodialisa sebelum diberikan terapi musik terhadap 66 responden didominasi dengan kategori pasien dengan depresi normal 26 responden $(42,4 \%)$, depresi sedang 19 responden $(28,8 \%)$, depresi ringan 14 responden
$(21,2 \%)$, depresi berat 5 responden $(7,6 \%)$ dan setelah diberikan terapi didominasi pasien dengan kategori depresi normal 38 responden $(57,6 \%)$, depresi ringan 24 responden $(36,4 \%)$, depresi sedang 4 responden $(6,1 \%)$, dan depresi berat setelah diberikan terapi musik sudah terasi sehingga sudah tidak ada responden dengan depresi berat.

Ada perubahan tingkat depresi pada pasien yang menjalani terapi hemodialisa. Indikator pre terapi dan post terapi menggunakan uji wilcoxon dengan nilai $\mathrm{p}<0,05$.

Berdasarkan beberapa keterbatasan penelitian ini, maka peneliti menyarankan beberapa sebagai berikut:

1. Teoritis

a) Peneliti

Peneliti diharapkan dapat mempublikasikan hasil ini secara luas kepada teman-teman seprofesi melalui media elektronik atau sosial.

b) Peneliti selanjutnya

Perlu dilakukan penelitian selanjutnya mengenai faktor-faktor yang mempengaruhi depresi pada pasien gagal ginjal kronik yang menjalani hemodialisa, atau perbedaan tingkat depresi pada pasien gagal ginjal kronik yang menjalani hemodialisa dan yang menjalani CAPD (Continous Ambulatory Peritoneal Dialysis).

c) Pendidikan

Hasil penelitian ini dapat digunakan sebagai referensi dalam pengembangan ilmu keperawatan.

2. Praktis

a) Pasien dan perawat

Dari hasil penelitian ini menunjukan ada pengaruh terapi musik terhadap tingkat depresi pada pasien gagal ginjal kronik yang 
menjalani hemodialisa. Diharapkan perawat dan pasien mampu membina hubungan emosinal yang baik untuk mengendalikan angka depresi pada pasien khususnya pada pasien gagal ginjal kronik yang baru awal melakukan terapi hemodialisis.

b) Rumah Sakit

Terapi musik tradisional diharapkan dapat menjadi salah satu intervensi keperawatan dalam menurunkan tingkat depresi. Hal ini bisa dijadikan pertimbangan oleh unit pelayanan untuk menyediakan fasilitas untuk pelaksanaan terapi musik.

\section{DAFTAR RUJUKAN}

Beck, A.T., Steer, R.A., \& Brown G.K.(1996). Beck Depression Inventory Manual(2nd). San Antonio : TX. Psychological Corporation.

Canisti, R. (2007, 21 Desember 2015). Gambaran Kecemasan dan Depresi pada penderita Gagal Ginjal Kronis yang Menjalani Hemodialisa.

Indonesian nursing. (2008, 18 Januari 2014). Faktor-faktor yang mempengaruhi ketidakpatuhan perawatan hemodialisis. Diperoleh dari http://indonesian nursing.com/?=192.

Keliat, B.A., Wiyono, A.P., \& Susanti, H. (2011). Manajemen Kasus Gangguan Jiwa. Jakarta : EGC

National Kidney and Urologi Disease Information Clearinghouse. (2006). Thretment Methods for Kidney Failure : Hemodialisis, the National Institute of Diabetes and
Digestive and Kidney Diseases (NIDDK). USA.

Nursalam. (2014). Metodologi Penelitian Ilmu Keperawatan : Pendekatan Praktis, Edisi 3. Jakarta : Salemba Medika

Penyunting : Giri. Yogyakarta : Media Pressindo.

Smeltzer, S. C., \& Bare, B. G. (2002). Buku Ajar

KeperawatanMedikalBedah. Jakarta: EGC.

Smeltzer, S.C., \& Bare, B.G. (2001). Buku Ajar Keperawatan Medikal Bedah Brunner \& Suddart (Ed. 8.vol.1).Alih bahasa : H.Kuncara, A. Hartono, M. Ester, Y. Asih. Jakarta : EGC.

Suwitra, K. (2009). Buku Ajar Ilmu Penyakit Dalam. Jakarta : Interna Publishing.

World Health Organization. (2015). Noncommunicable Disease and their Risk Factors : UN Task Force on NCDs : Joint UN Action to Respond to the Challenge of Noncommunicable Disease in Sri Lanka, 